\title{
Plasma pyridoxal phosphate and pyridoxic acid and their relationship to plasma homocysteine in a representative sample of British men and women aged 65 years and over
}

\author{
C. J. Bates ${ }^{1 *}$, K. D. Pentieva ${ }^{1}$, A. Prentice ${ }^{1}$, M. A. Mansoor ${ }^{3}$ and S. Finch ${ }^{2}$ \\ ${ }^{1}$ MRC Human Nutrition Research, Downhams Lane, Milton Road, Cambridge CB4 IXJ, UK \\ ${ }^{2}$ Social and Community Planning Research, 35 Northampton Square, London ECIV OAX, UK \\ ${ }^{3}$ Division of Clinical Chemistry, Central Hospital in Rogaland, 4003 Stavanger, Norway
}

(Received 1 December 1997 - Revised 13 August 1998 - Accepted 28 August 1998)

\begin{abstract}
Concentrations of pyridoxal phosphate and pyridoxic acid were measured in fasting plasma samples from British men and women aged 65 years and over, participating in a National Diet and Nutrition Survey during 1994-5, selected to be representative of the population of mainland Britain. In this population, the concentration of pyridoxal phosphate declined, whereas pyridoxic acid rose, with increasing age and frailty; however, both status indicators were strongly and directly (with a positive coefficient) correlated with estimates of vitamin $\mathrm{B}_{6}$ intake. This was little affected by the inclusion of food energy and protein intakes in the model. Forty-eight percent of the participants living in the community and $75 \%$ of those living in institutions had plasma pyridoxal phosphate concentrations below a range considered normal from other studies. In a univariate regression model, plasma pyridoxal phosphate concentrations were inversely correlated with plasma homocysteine concentrations, consistent with the hypothesis that vitamin $\mathrm{B}_{6}$ status may influence plasma homocysteine levels, and hence vascular disease risk. However, this relationship was partly attenuated in a multiple regression model including age, sex, domicile and biochemical status indices, including those of folate and vitamin $\mathrm{B}_{12}$. There was evidence that plasma pyridoxal phosphate was sensitive to metabolic conditions associated with inflammation and the acute-phase reaction, and that plasma pyridoxic acid was sensitive to renal function. Thus, neither index is an ideal predictor of vitamin $\mathrm{B}_{6}$ status in older people, unless these confounding factors are allowed for. Since poor vitamin $\mathrm{B}_{6}$ status may have health implications, e.g. for immune function, cognition, and for essential intermediary metabolic pathways in older people, it needs to be investigated as a possible public health problem.
\end{abstract}

Vitamin $B_{6}$ : Pyridoxal phosphate: Dietary survey: Elderly

Vitamin $\mathrm{B}_{6}$ is an essential dietary constituent for man, and a precursor of the enzyme cofactors pyridoxal $5^{\prime}$-phosphate and pyridoxamine $5^{\prime}$-phosphate, which form the active site of a wide range of essential enzymes in living tissues. Biochemical indices of vitamin $\mathrm{B}_{6}$ status in human subjects have been based on a wide variety of procedures and analytes, and one of the most popular choices at the present time is plasma pyridoxal phosphate concentration (Bates, 1997). Recent advances in the design of high-sensitivity fluorescence detectors for HPLC assay systems have brought this assay within the reach of laboratories which specialize in the measurement of biochemical indices of micronutrient status (Bates et al. 1998). Whereas circulating pyridoxal phosphate is a biologically active form of the vitamin which is available for use by the tissues, 4-pyridoxic acid is biologically inactive and represents a major vitamin $\mathrm{B}_{6}$ catabolite, destined for excretion in the urine. Its relation to vitamin $\mathrm{B}_{6}$ intake and status may differ from that of pyridoxal phosphate, and it may therefore provide complementary information.

Studies of older people from countries outside Britain (Rose et al. 1976; Lowik et al. 1989) have indicated that vitamin $\mathrm{B}_{6}$ biochemical status indices frequently decline towards deficient values with advancing age; however, the implications for health are not clear. Older people who live in institutions may be particularly at risk (Chen \& FanChiang, 1981; Lowik et al. 1992). It was therefore important to examine a British population, since there are few recent British studies, and to characterize the status of the oldest group (85+ years) and of those living in institutions such as nursing homes. There is a need for clarification of the relationship of the vitamin $\mathrm{B}_{6}$ status indices with food 
energy and protein intakes, as well as with vitamin $\mathrm{B}_{6}$ intakes, and of their relationship with sex and with potentially confounding factors such as renal function and acutephase status. The purpose of the present paper is, therefore, to examine these questions by reporting the results of measurements of pyridoxal 5'-phosphate and of pyridoxic acid in plasma samples from a recent British survey of people aged 65 years and over (Finch et al. 1998).

The National Diet and Nutrition Survey series is a rolling series of surveys of different age groups of the British population, commissioned jointly by the Department of Health and the Ministry of Agriculture, Fisheries and Food, which focus on diet, biochemical status, anthropometry and lifestyle, including various risk factors which may impinge on long-term health. This survey of older people living in the UK, and the blood samples thereby generated, has provided an opportunity for appraisal of their vitamin $\mathrm{B}_{6}$ intakes and status.

One clinically important factor for which vitamin $B_{6}$ intakes and status are potentially relevant is the control of plasma homocysteine concentration, which is an independent risk factor for, and index of, vascular diseases (Boushey et al. 1995; Graham et al. 1997). It may be influenced by several B-vitamins, including vitamin $\mathrm{B}_{6}$ (Smolin \& Benevenga, 1982; Brattstrom et al. 1990; Miller et al. 1992, 1994; Hu et al. 1993; Joosten et al. 1993; Selhub et al. 1993; Ubbink et al. 1993, 1996; Franken et al. 1994; Dalery et al. 1995; Ellis \& McCully, 1995; Naurath et al. 1995; Riggs et al. 1996; Verhoef et al. 1996). Therefore, since plasma homocysteine concentrations were measured on a subset of the survey samples (Bates et al. 1997), it was important to explore the relationships between vitamin $\mathrm{B}_{6}$ status and plasma homocysteine and to ask whether the variation in vitamin $\mathrm{B}_{6}$ indices contributed independently to inter-subject variations in plasma homocysteine concentration, or whether they represented a proxy for other determinants.

\section{Subjects and methods}

The design and execution of the National Diet and Nutrition Survey of people aged 65 years and over has been described (Finch et al. 1998); therefore only the main features are summarized here. Permission for the survey procedures was obtained from Local Research Ethics Committees associated with each postcode sector, and the MRC Dunn Nutrition Unit's Ethics Committee. The survey approached 2626 people aged 65 years and over, of whom $2172(83 \%)$ were living in the community and $454(17 \%)$ were living in institutions, such as nursing homes. Of these, 1275 who were not in institutions and 412 who were in institutions provided a full $4 \mathrm{~d}$ weighed record of food and drink consumed (59\% and $91 \%$ response rates respectively). A total of 986 of those not living in institutions and 290 of those living in institutions provided a blood sample, usually in the early morning, after an overnight fast (45\% and $64 \%$ response rates respectively).

Although it is clearly impossible to eliminate selection bias completely, especially in a survey of frail elderly people, from whom a considerable amount of voluntary cooperation is requested, a number of precautions were taken to try to minimize the potential selection bias problem (Finch et al. 1998). Identification of the eligible sample and subsequent selection of those to be approached was performed by strictly random procedures. Use of proxy informationgivers where necessary, ensured that even confused elderly people could be, and were, included. Use of a weighting variable, to correct for the effects of disproportionate sampling, was applied both in the survey report (Finch et al. 1998) and, where necessary, in the present study. The weighted samples had similar profiles for sex, age and region as those of the population aged 65 years and over from the 1991 census data. If all the participating subjects, including those who achieved only partial participation, were subdivided according to whether they provided both a blood sample and a full $4 \mathrm{~d}$ diet record, or one of these, or neither, then those that provided neither were slightly older (by an average of 1.4 years), and they were more likely to be female and to be living alone, than those who provided both. Such biases were corrected, where necessary, by use of the weighting variable.

From the eighty randomly-selected postcode sectors from mainland Britain, the participating subjects were stratified into six subgroups, by age and sex from each of (a) freeliving and (b) institution-living (generally nursing home) groups, thus yielding twelve subgroups altogether. The sample of people in institutions was drawn by selecting residential and nursing homes for elderly people in the same postal sectors as the non-institution sample and then randomly selecting three residents from each institution. A fieldworker invited participation, comprising an interview about health and lifestyle, a $4 \mathrm{~d}$ weighed dietary record, anthropometric, blood pressure and grip strength measurements, and providing a urine sample and an early morning blood sample, usually fasting. Fieldwork took place from October 1994 to September 1995 in four 3-month waves, in order to take account of possible seasonal variations in food availability and biochemical status.

Participants living in their own homes (or their carers, where proxy information was obtained), completed $4 \mathrm{~d}$ weighed records under the supervision of trained fieldworkers. They kept written, structured diary records of all items of food and drink, including snacks, with weights of containers plus food and containers with leftovers, to allow for plate waste. The fieldworkers verified the records with the participants (or carers), checking for information quality, consistency, and agreement with a qualitative diet recall on the subsequent day. For participants living in institutions, it was necessary to modify the dietary assessment method, as they did not prepare or serve their own meals. Records were kept by carers and meals were, where necessary, weighed by the fieldworkers. Compared with the non-institution sample, it is less likely that any under-recording due to omission of items of food or drink would have occurred, but it is possible that plate waste may have been under-recorded, resulting in over-estimation of intakes in some instances. Because of the methodological differences, comparisons of nutrient intakes between subjects in institutions and those not living in institutions should be treated with caution. Diet records were coded at Social and Community Planning Research, and were used to calculate individual daily nutrient intakes using a specially developed nutrient databank, based 
on standard food composition tables. Estimates of additional vitamin intakes from vitamin supplements (tablets, syrups, etc.) were included; these were used during the $4 \mathrm{~d}$ dietary recording period by about $20 \%$ of participants not living in institutions and by about $14 \%$ of those in institutions. These estimates are lower than those for "non-prescribed dietary supplements' in the survey report (Finch et al. 1998), partly because the latter included supplements that did not provide vitamins or minerals, and partly because they included supplements which were not taken during the $4 \mathrm{~d}$ diet estimate, because they were taken less frequently.

A blood sample was taken by a nurse in the subject's home and was subdivided for measurements of haematological indices, clotting factors and biochemical indices. A heparinized subsample was taken in a cool-box to a local hospital laboratory, usually within $4 \mathrm{~h}$, and plasma was separated and stored frozen for periods of up to 3 years, at $-80^{\circ}$ for the majority of this storage period, before the analyses of pyridoxal phosphate and pyridoxic acid.

In order to investigate possible differences in vitamin $\mathrm{B}_{6}$ status between young people and older adults, sixty-six samples of heparinized plasma from the feasibility study for the National Diet and Nutrition Survey of Young People Aged 4-18 Years (S Lowe, unpublished results) were analysed. The average age of these young participants was 12.5 years, and the samples were analysed by exactly the same procedures, so as to provide a direct status-comparison between the young and old age groups.

Analyses of plasma pyridoxal phosphate were performed by the procedure of Bates et al. (1998). Briefly, $120 \mu \mathrm{l}$ samples of plasma were thawed in a semi-darkened room, and were mixed with $60 \mu \mathrm{l}$ water, followed by $200 \mu \mathrm{l}$ TCA $(100 \mathrm{~g} / \mathrm{l})$ to give a final TCA concentration of $50 \mathrm{~g} / \mathrm{l}$. The mixture was maintained at $50^{\circ}$ for 5 min in the dark; it was centrifuged, and the supernatant fraction was then mixed with potassium cyanide in a buffered alkaline solution containing $\mathrm{K}_{2} \mathrm{HPO}_{4}$. After $25 \mathrm{~min}$ at $50^{\circ}$ in the dark, the solution was reacidified with phosphoric acid, and $100 \mu \mathrm{l}$ was injected into the HPLC system. This was based on a Waters Symmetry Shield RP8 (Waters Ltd, Watford, Herts., UK), $5 \mu, 4.6 \times 250 \mathrm{~mm}$ column, with isocratic eluent flowing at $1.5 \mathrm{ml} / \mathrm{min}$. The eluent contained semicarbazide, $75 \mathrm{mmol} / \mathrm{l}$, and $\mathrm{KH}_{2} \mathrm{PO}_{4}, 50 \mathrm{mmol} / 1, \mathrm{pH} 2.85$ in water. The fluorescent derivative of pyridoxal phosphate (i.e. pyridoxic acid phosphate) eluted after approximately $4.7 \mathrm{~min}$, and the unchanged fluorescent pyridoxic acid eluted after $8.5 \mathrm{~min}$. Both were detected with a Waters 474 Scanning Fluorescence Detector (Waters Ltd), excitation wavelength $325 \mathrm{~nm}$; emission wavelength $418 \mathrm{~nm}$; emission bandwidth $40 \mathrm{~nm}$; flow cell volume $16 \mu \mathrm{l}$. The run time was $10 \mathrm{~min}$ per sample and the throughput was about forty samples or standards per $8 \mathrm{~h}$ day. Calibration was by external pyridoxal phosphate and pyridoxic acid standards in water $(5-100 \mathrm{nmol} / \mathrm{l})$, and quality control was by a pooled normal heparinized sample, subdivided into small portions, and stored below $-80^{\circ}$. The between-run $\mathrm{CV}$ of the estimate for this quality assurance control $(11.9 \mu \mathrm{mol} / 1$ pyridoxal phosphate) was $3.5 \%$, and the $\mathrm{CV}$ of between-run duplicates for unknowns was $2-4 \%$ at medium to high values. Similar between-run imprecision was found for pyridoxic acid.

The plasma total homocysteine assay procedure has been described previously (Mansoor et al. 1992). Briefly, the plasma samples were treated with sodium borohydride to reduce disulfide bonds, with sulfosalicyclic acid to remove protein, with monobromobimane to yield a fluorescent product, followed by HPLC with fluorescence detection. This assay also quantitated plasma cysteine and cysteinylglycine in the same run.

Data reduction was performed with 'Excel' (version 5.0, Microsoft Corp., USA) and 'DataDesk' (Data Descriptions Inc., Ithaca, NY, USA) computer programmes. Because the pyridoxal phosphate and pyridoxic acid concentrations, the vitamin $\mathrm{B}_{6}$ intakes and many of the other indices were not normally distributed, logarithmic transformation was used for most of the calculations. ANOVA, Student's $t$ test, and univariate and multivariate linear regression were used. $P<0.05$ was taken as the criterion of statistical significance.

\section{Results}

Table 1 shows the arithmetic and geometric mean concentrations of the two forms of vitamin $\mathrm{B}_{6}$ in plasma, the participants having been subdivided by age, sex and type of domicile. The overall significance of the inter-group differences (twelve groups) for log(plasma pyridoxal phosphate), by ANOVA, was $F 13.6, P<0.0001$. The relationship of $\log$ (pyridoxal phosphate) with age (sexes combined) was significant and inverse by linear regression $(t-4 \cdot 1, P<$ $0.0001)$ for the non-institution group, but it was nonsignificant $(t+0 \cdot 3)$ for the institution group. There was no significant sex difference, by regression. For log(plasma pyridoxic acid), the overall significance of the inter-group differences (twelve groups) by ANOVA was $F 4.3, P<$ 0.0001 . The relationship with age (sexes combined) was significant and direct by linear regression $(t+6 \cdot 6, P<$ 0.0001 for the non-institution group and $t+2 \cdot 5, P=0 \cdot 01$ for the institution group). Again, there were no significant sex differences. After adjustment for age and sex, by multiple regression, people living in institutions had significantly lower values of $\log$ (pyridoxal phosphate) than those living in the community $(t 9.2 ; P<0.0001)$, but $\log$ (pyridoxic acid) did not differ between the two types of domicile $(t 1 \cdot 6$; $P=0 \cdot 1)$. Examination of interaction effects revealed the following significant interactions in a multivariate regression model: for pyridoxal phosphate, age $\times$ sex (inverse, $P=0.0004) ;$ sex $\times$ domicile (inverse, $P=0.0005$ ); age $\times$ domicile (inverse, $P<0.0001$ ); age $\times$ sex $\times$ domicile (direct, $P=0.0002$ ); and for pyridoxic acid, age $\times$ domicile (inverse, $P=0.0002)$.

It is clear that the pyridoxal phosphate concentrations were higher in the non-institution than the institution group and that there was a significant trend towards lower values with increasing age. Sex alone, however, exhibited no significant relationship with pyridoxal phosphate. For pyridoxic acid, there was a marked upward trend with age, but there were no significant differences associated with sex or with domicile group. There were no significant differences in either of the vitamin $\mathrm{B}_{6}$ indices between people who were living on their own, and people who were living with others, in the non-institution group (results not shown). A weighting-factor adjustment for differences in age, sex, domicile 
Table 1. Plasma concentrations of pyridoxal phosphate and pyridoxic acid, by age, sex and domicile categories, in people aged 65 years and over*

(Arithmetic mean values with standard deviations, and geometric mean values)

\begin{tabular}{|c|c|c|c|c|c|c|c|}
\hline Category & $n$ & \multicolumn{3}{|c|}{ Plasma pyridoxal phosphate (nmol/l) } & \multicolumn{3}{|c|}{ Plasma pyridoxic acid (nmol/l) } \\
\hline Non-institution, & & UW & UW & UW (W) & UW & UW & UW (W) \\
\hline $\begin{array}{l}65-74 \text { years } \\
75-84 \text { years } \\
85+\text { years }\end{array}$ & $\begin{array}{r}211 \\
193 \\
68\end{array}$ & $\begin{array}{l}42 \cdot 3 \\
39 \cdot 1 \\
35 \cdot 7\end{array}$ & $\begin{array}{l}28 \cdot 7 \\
25 \cdot 3 \\
23 \cdot 4\end{array}$ & $\begin{array}{l}36.4(36.6) \\
33.3(33.4) \\
29.3(23.9)\end{array}$ & $\begin{array}{l}15 \cdot 8 \\
17 \cdot 8 \\
23 \cdot 2\end{array}$ & $\begin{array}{r}9.7 \\
9.8 \\
12.9\end{array}$ & $\begin{array}{l}14.0(14 \cdot 1) \\
15 \cdot 8(16 \cdot 0) \\
20.6(20 \cdot 7)\end{array}$ \\
\hline $\begin{array}{c}\text { Institution, males } \\
65-74 \text { years } \\
75-84 \text { years } \\
85+\text { years }\end{array}$ & $\begin{array}{l}26 \\
58 \\
53\end{array}$ & $\begin{array}{l}26 \cdot 7 \\
23 \cdot 2 \\
23 \cdot 4\end{array}$ & $\begin{array}{l}22.8 \\
14.9 \\
18.1\end{array}$ & $\begin{array}{l}22.4(21.3) \\
19.1(19.0) \\
20.3(19.2)\end{array}$ & $\begin{array}{l}18 \cdot 1 \\
16 \cdot 2 \\
20 \cdot 6\end{array}$ & $\begin{array}{r}18 \cdot 1 \\
9.7 \\
12 \cdot 4\end{array}$ & $\begin{array}{l}13.7(12.8) \\
14.1(13.9) \\
17.8(17.9)\end{array}$ \\
\hline
\end{tabular}

UW, unweighted data; $W$, data adjusted by a weighting factor, designed to eliminate biases in age, sex, domicile etc. (see p. 192).

* All subjects from whom the biochemical status measurements were obtained were included in this analysis.

and geographical distribution between the selected sample and the entire UK population aged 65 years or over, made little difference to the calculated values (Table 1).

Of the respondents, 157 (13.4\% of those with vitamin $\mathrm{B}_{6}$ status assays) had eaten or drunk something since the evening before their blood sample was taken, but there was no significant difference between the log mean pyridoxal phosphate or pyridoxic acid values for these nonfasting samples and the corresponding values from the
$86.6 \%$ who had not eaten or drunk anything during the same period (results not shown).

Table 2 shows vitamin $B_{6}$ intake estimates, together with food energy and protein intake estimates, for the twelve groups of participants shown in Table 1. Energy and protein intakes were normally distributed, but vitamin $\mathrm{B}_{6}$ intakes were positively skewed and were therefore log-transformed. Because nutrient density may be more important in determining vitamin $\mathrm{B}_{6}$ status than total daily vitamin $\mathrm{B}_{6}$ intake,

Table 2. Intakes of food energy, protein and vitamin $B_{6}$, by age, sex and domicile categories, in people aged 65 years and over

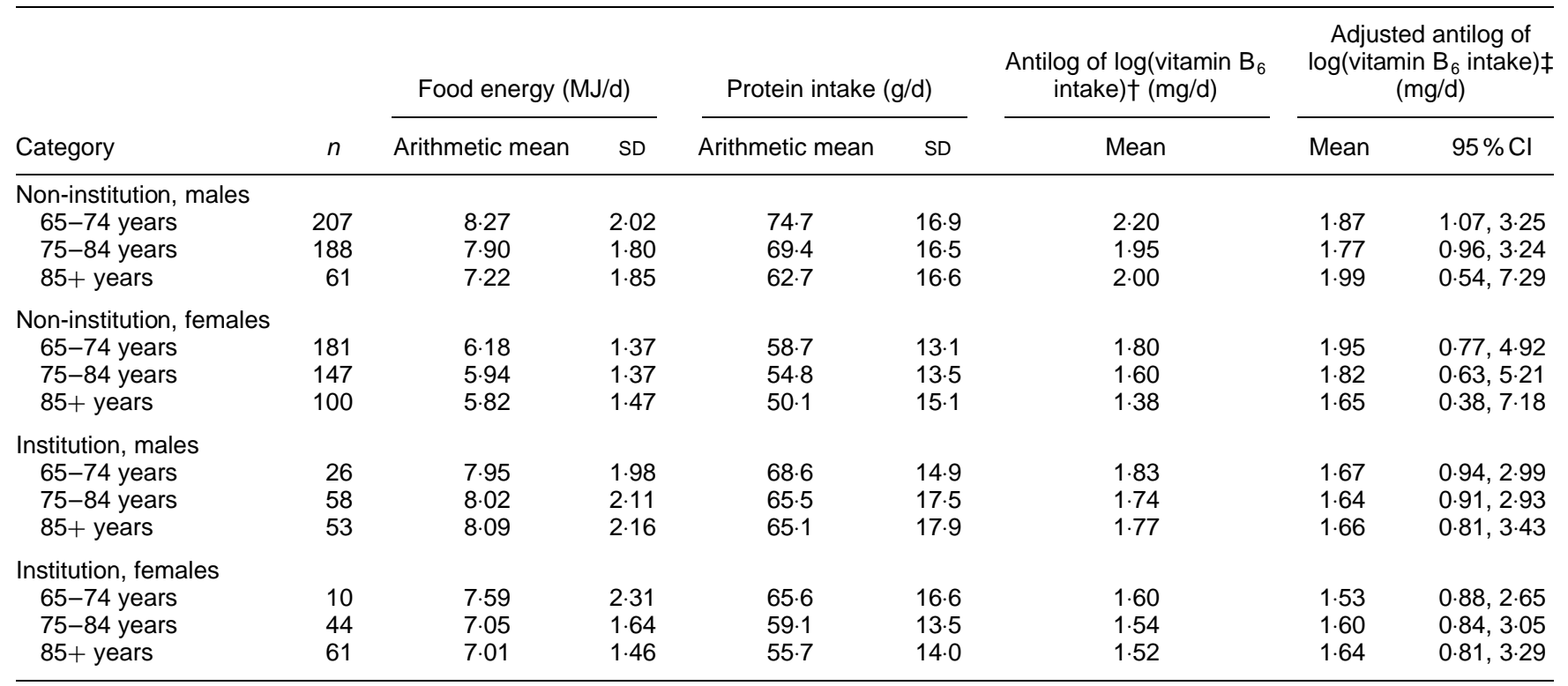

\footnotetext{
* The estimates were confined to those subjects who also provided a blood sample for the biochemical indices, and all were adjusted by a population weighting factor, as described on p. 192.

† Without adjustment for energy and protein intakes.

$\ddagger$ Adjusted for energy and protein intakes.
} 
when comparing individuals with each other, an estimate which was adjusted for energy and protein intakes is also included in Table 2. In a multiple regression model, age, sex and domicile were all significantly $(P<0.0001)$ related to energy intake, which decreased with age, was higher in males than females, and was higher in the institution than in non-institution groups. For protein intake, there were similar relationships with age and sex, but there was no significant difference between institution and non-institution domicile. $\log \left(\right.$ vitamin $\mathrm{B}_{6}$ intake), on a total daily intake basis, declined significantly with age $(P<0.0001)$ and was higher in men than women $(P<0 \cdot 0001)$, but there were no significant differences between institution and non-institution groups. However, when protein and energy intakes were included in the regression model, the relationships between vitamin $\mathrm{B}_{6}$ intake and age or sex became non-significant. It appears that the intergroup differences in vitamin $\mathrm{B}_{6}$ intake were not attributable to differences in the vitamin $\mathrm{B}_{6}$ : protein ratio.

Both vitamin $\mathrm{B}_{6}$ status indices (plasma pyridoxal phosphate and pyridoxic acid) were strongly correlated with vitamin $\mathrm{B}_{6}$ intake (Table 3 ). The effects of adjustment for

Table 3. Linear regression analysis showing the interdependence of the biochemical status indices and vitamin $B_{6}$ intakes*

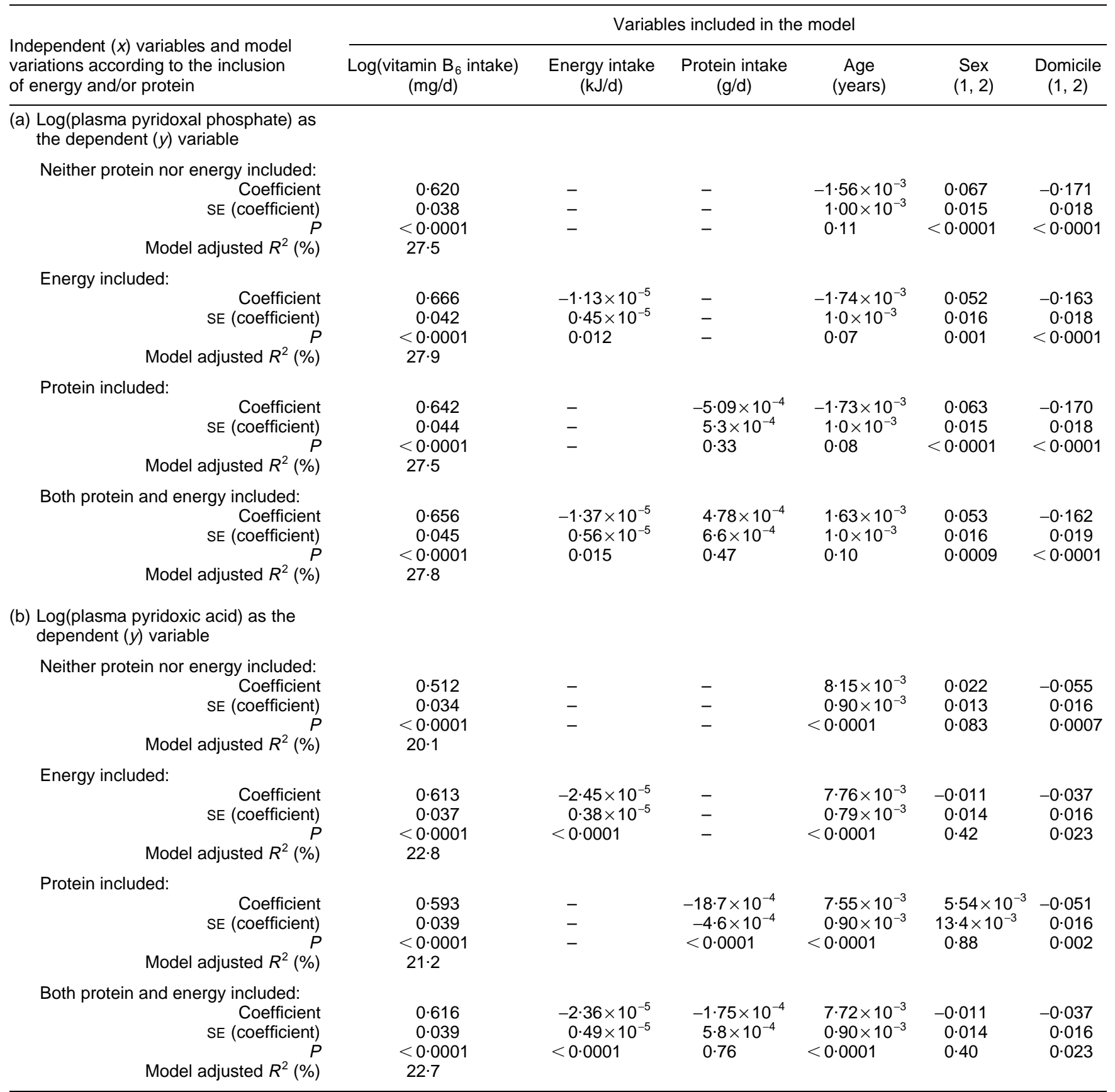

* The analysis involved 1136 sets of data. For details, see p. 192. 


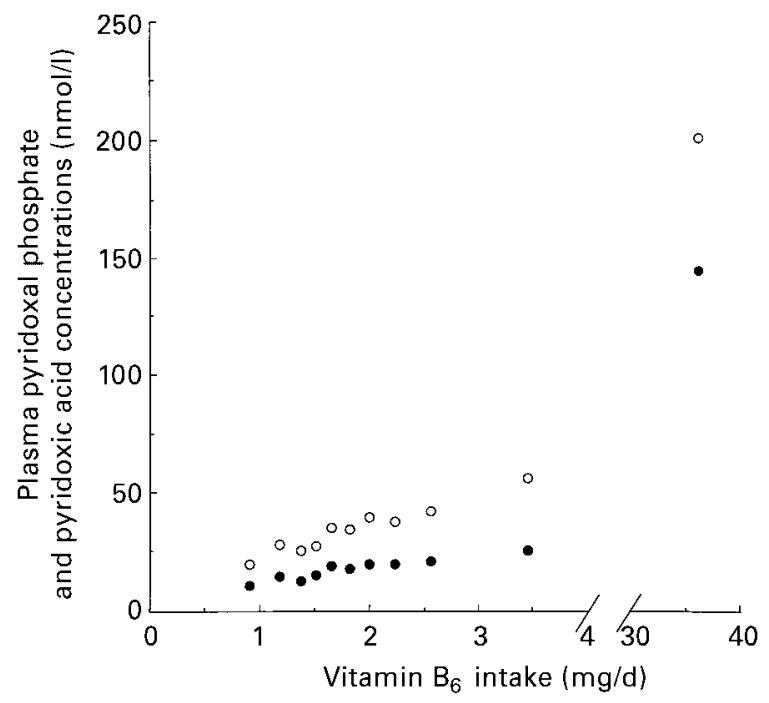

Fig. 1. Relationship of plasma pyridoxal phosphate $(O)$ and pyridoxic acid $(\bullet)$ to vitamin $B_{6}$ intake in subjects from the National Diet and Nutrition Survey: People Aged 65 Years and Over. Vitamin $B_{6}$ intakes between $0.135 \mathrm{mg} / \mathrm{d}$ (lowest) and $6.0 \mathrm{mg} / \mathrm{d}$ were divided into ten equal segments. Not all of the participants provided a blood sample for the plasma assays; there were between 105 and 124 subjects with plasma index measurements in each segment. There were seven subjects with higher intakes, between 6.0 and $101.8 \mathrm{mg} / \mathrm{d}$, whose mean values are shown to the right of the figure. For each segment, the mean plasma concentrations of pyridoxal phosphate and pyridoxic acid were calculated, with adjustments (by linear regression) for age, sex, type of domicile, and intakes of energy and protein.

energy or protein intake, or both, and the effects of including age and sex on these relationships, were minimal. Therefore, either the total daily intake of the vitamin, or its ratio to food energy or protein, can predict the status indices.

Fig. 1 shows the relationships between the two biochemical status indices, plasma pyridoxal phosphate and plasma pyridoxic acid as $y$ variables, and adjusted vitamin $\mathrm{B}_{6}$ intake as the $x$ variable. Subjects with mean daily vitamin $\mathrm{B}_{6}$ intakes below $4.0 \mathrm{mg}$ were divided into ten groups with increasing intakes, and the seven remaining subjects with higher intakes (above $4.0 \mathrm{mg} / \mathrm{d}$ ) formed a separate, eleventh group. Fig. 1 shows that both indices increased progressively with increasing intakes, although pyridoxal phosphate increased more steeply and consistently than pyridoxic acid, especially over the lower intake range.

Since there was a significant downward trend in plasma pyridoxal phosphate with increasing age, and an upward trend in plasma pyridoxic acid with increasing age (Table 1 ), it was of interest to compare these indices between people aged 65 years or over, and a smaller group of young people, average age 12.5 years. The result of this comparison is shown in Table 4. The young people had considerably higher plasma pyridoxal phosphate concentrations, and lower pyridoxic acid concentrations, than the older age group. These age differences remained highly significant even after removal of those subjects (in the older group) who had some evidence of poor renal function, i.e. plasma urea concentrations $>10 \mathrm{mmol} / \mathrm{l}$ (results not shown).

Table 5 explores the relationship between the biochemical indices of vitamin $\mathrm{B}_{6}$ status and the concentration of homocysteine in the same plasma samples (see Bates et al. 1997). In a univariate linear regression, with no other determinants, the inverse relationship between plasma pyridoxal phosphate and homocysteine concentrations was strong $(t-11.0, P<0.0001)$, but it became progressively weaker as other determinants were added, in a multiple regression model. With age, sex, domicile, serum and erythrocyte folate and serum vitamin $\mathrm{B}_{12}$ included, it was still significant at $t-2 \cdot 4, P=0 \cdot 019$. There were moderately strong direct relationships between plasma pyridoxal phosphate (or pyridoxic acid) and other B-vitamin status indices such as serum and erythrocyte folate or serum vitamin $B_{12}$ ( $t$ ratios from $6 \cdot 1$ to $13 \cdot 4 ; R^{2}$ from 4 to $14 \%$ of the variance explained, in a simple univariate regression model). This covariance of B-vitamin status indices may be one of the reasons for the reduced significance of plasma pyridoxal phosphate in the full multivariate model. For pyridoxic acid, the relationship with plasma homocysteine paradoxically became a direct positive relationship with some of the combinations of determinants. Two other S-containing compounds in plasma, cysteine and cysteinylglycine, were less strongly related to the vitamin $\mathrm{B}_{6}$ status indices (results not shown). Cysteinylglycine exhibited a moderately strong direct relationship with both pyridoxal phosphate and pyridoxic acid; cysteine was weakly related to pyridoxic acid but not at all to pyridoxal phosphate (results not shown).

Table 4. Comparison between people aged 65 years and over and young people, average age 12.5 years, with respect to their plasma pyridoxal phosphate and pyridoxic acid concentrations*

(Log mean values and standard deviations; antilog of log mean and $95 \%$ confidence intervals)

\begin{tabular}{|c|c|c|c|c|c|c|c|c|}
\hline \multirow[b]{2}{*}{ Category } & \multicolumn{4}{|c|}{ Plasma pyridoxal phosphate } & \multicolumn{4}{|c|}{ Plasma pyridoxic acid } \\
\hline & Log mean & SD & Antilog of log mean & $95 \% \mathrm{Cl}$ & Log mean & SD & Antilog of log mean & $95 \% \mathrm{Cl}$ \\
\hline $\begin{array}{l}\text { People aged } \\
65 \text { years or over }\end{array}$ & 1.504 & 0.285 & 31.9 & $8 \cdot 6,118 \cdot 6$ & $1 \cdot 172$ & 0.243 & 14.9 & $4 \cdot 8,45 \cdot 5$ \\
\hline $\begin{array}{l}\text { Young people } \\
\text { aged } 4-18 \text { years }\end{array}$ & 1.753 & $0 \cdot 164$ & $56 \cdot 6$ & $26 \cdot 6,120 \cdot 5$ & 1.088 & 0.155 & $12 \cdot 2$ & $6 \cdot 0,25 \cdot 0$ \\
\hline $\begin{array}{l}\text { Student's } t \text { test } \\
\text { between age } \\
\text { groups }\end{array}$ & $t 11.4$ & & & & $t 4.4$ & & & \\
\hline$P$ for difference & $<0.0001$ & & & & $<0.0001$ & & & \\
\hline
\end{tabular}

* The group of people aged 65 years and over comprised all subjects who yielded vitamin $\mathrm{B}_{6}$ status analyses in this survey, adjusted by a weighting factor as described on p. 192. The group of young people was not a random sample of the British population, but was typical of their age group. 
Table 5. Linear regression analysis of log(total plasma homocysteine) $v$. log(plasma pyridoxal phosphate) or log(plasma pyridoxic acid), with adjustment for other determinants

\begin{tabular}{|c|c|c|c|c|c|c|c|c|c|c|c|c|}
\hline \multirow{3}{*}{$\begin{array}{l}\text { Multivariate regression } \\
\text { model containing: }\end{array}$} & \multicolumn{12}{|c|}{ Log(total plasma homocysteine) } \\
\hline & \multicolumn{6}{|c|}{ Analysis for log(plasma pyridoxal phosphate) } & \multicolumn{5}{|c|}{ Analysis for log(plasma pyridoxic acid) } & \multirow[b]{2}{*}{$P$} \\
\hline & $\mathrm{df}$ & $t$ & Coefficient & SE (coefficient) & Adjusted $R^{2}$ & $P$ & df & $t$ & Coefficient & SE (coefficient) & Adjusted $R^{2}$ & \\
\hline \multirow{4}{*}{$\begin{array}{l}\text { No other determinants } \\
\text { Serum and erythrocyte folates } \\
\text { Serum and erythrocyte folates } \\
\text { and serum vitamin } B_{12} \\
\text { Age, sex, domicile, } \\
\text { serum and erythrocyte folates } \\
\text { and serum vitamin } B_{12}\end{array}$} & 931 & -11 & -0.202 & 0.018 & 11.4 & $<0.0001$ & 930 & $-2 \cdot 4$ & -0.056 & 0.023 & 0.5 & 0.017 \\
\hline & 902 & $-5 \cdot 3$ & $-0 \cdot 101$ & 0.019 & $24 \cdot 1$ & $<0.0001$ & 901 & +3.8 & +0.085 & 0.023 & $22 \cdot 9$ & 0.0002 \\
\hline & 895 & -4.5 & -0.084 & 0.019 & $27 \cdot 3$ & $<0.0001$ & 894 & +4.5 & +0.100 & 0.022 & $27 \cdot 3$ & $<0.0001$ \\
\hline & 892 & $-2 \cdot 4$ & -0.045 & 0.019 & $32 \cdot 1$ & 0.019 & 891 & $+3 \cdot 3$ & +0.072 & 0.022 & $32 \cdot 4$ & 0.001 \\
\hline
\end{tabular}

Plasma pyridoxal phosphate was not strongly correlated with the indices of renal function (plasma urea and creatinine), whereas pyridoxic acid was positively and strongly related to these indices. Conversely, pyridoxic acid was not strongly correlated with indices of acute-phase status (e.g. plasma $\alpha_{1}$-antichymotrypsin; $\mathrm{Cu}$; blood leucocyte count), whereas pyridoxal phosphate was inversely correlated with these indices. Nearly all of these correlations remained highly significant after adjustment for age, sex, domicile and vitamin $\mathrm{B}_{6}$ intakes.
There was evidence of a moderate seasonal variation in plasma pyridoxal phosphate concentrations (Table 6) with the lowest values occurring in the winter season (January to March) and the highest in the summer (July to September). This characteristic pattern of seasonal variation was not observed, however, for plasma pyridoxic acid or for vitamin $\mathrm{B}_{6}$ intakes.

Table 7 illustrates the variation of each of the two indices of vitamin $\mathrm{B}_{6}$ status and vitamin $\mathrm{B}_{6}$ intake, with the geographical regions of mainland Britain. It is clear that

Table 6. Seasonal variation of vitamin $\mathrm{B}_{6}$ status indices and intake in subjects from the National Diet and Nutrition Survey: People Aged 65 Years and Over*

\begin{tabular}{|c|c|c|c|c|}
\hline Index & $\begin{array}{c}\text { Wave } 1 \\
\text { (October-December) }\end{array}$ & $\begin{array}{c}\text { Wave } 2 \\
\text { (January-March) }\end{array}$ & $\begin{array}{c}\text { Wave } 3 \\
\text { (April-June) }\end{array}$ & $\begin{array}{c}\text { Wave } 4 \\
\text { (July-September) }\end{array}$ \\
\hline \multicolumn{5}{|c|}{ Plasma pyridoxal phosphate (nmol/l) } \\
\hline Mean & $38.0(39.9)$ & $33.4(35.8)$ & $38.2(40.6)$ & $42 \cdot 5(45 \cdot 2)$ \\
\hline \multicolumn{5}{|c|}{ Plasma pyridoxic acid (nmol/l) } \\
\hline Mean & $18.4(19.5)$ & $17.5(16.8)$ & $19.8(20 \cdot 1)$ & $18.1(17.8)$ \\
\hline Antilog of log(mean) & $15.2(14.6)$ & $14.7(14.2)$ & $16 \cdot 2(16 \cdot 1)$ & $15.1(14.7)$ \\
\hline Antilog of log(mean) & $1.9(1.9)$ & $1.8(1.8)$ & $1.7(1.8)$ & $1.8(1.8)$ \\
\hline
\end{tabular}

Table 7. Log-mean values of vitamin $\mathrm{B}_{6}$ status indicators by geographical regions of mainland Britain in subjects from the National Diet and Nutrition Survey: People Aged 65 Years and Over*

\begin{tabular}{|c|c|c|c|c|c|c|c|c|c|c|}
\hline \multirow[b]{2}{*}{ Region } & \multirow[b]{2}{*}{$n$} & \multicolumn{3}{|c|}{$\begin{array}{l}\text { Antilog of } \log _{10} \text { (plasma } \\
\text { pyridoxal phosphate) }\end{array}$} & \multicolumn{3}{|c|}{$\begin{array}{l}\text { Antilog of } \log _{10} \text { (plasma } \\
\text { pyridoxic acid) }\end{array}$} & \multicolumn{3}{|c|}{$\begin{array}{c}\text { Antilog of } \log _{10} \text { (vitamin } \\
\mathrm{B}_{6} \text { intake) }\end{array}$} \\
\hline & & $A$ & $\mathrm{~B}$ & $\mathrm{C}$ & $A$ & $\mathrm{~B}$ & $\mathrm{C}$ & $A$ & $\mathrm{~B}$ & $\mathrm{C}$ \\
\hline Northern England & $145-148$ & $27 \cdot 7$ & $24 \cdot 1$ & 24.6 & $12 \cdot 9$ & 12.5 & $12 \cdot 9$ & 1.65 & 1.59 & 1.65 \\
\hline Manchester/Liverpool & $111-120$ & $26 \cdot 6$ & $22 \cdot 1$ & 22.5 & $14 \cdot 1$ & 13.5 & 13.8 & 1.77 & 1.66 & 1.72 \\
\hline South Midlands & $197-199$ & 29.2 & $24 \cdot 7$ & $25 \cdot 2$ & 14.0 & 13.5 & 13.8 & 1.71 & 1.62 & 1.67 \\
\hline London and South East & $203-214$ & 37.2 & 29.4 & 28.5 & $16 \cdot 6$ & $15 \cdot 8$ & $15 \cdot 2$ & 1.98 & 1.87 & 1.77 \\
\hline Central Southern and & & & & & & & & & & \\
\hline $\begin{array}{l}\text { South West } \\
\text { ANOVA } F \text { ratio ( } 7 \mathrm{df})\end{array}$ & $214-224$ & $\begin{array}{l}35 \cdot 2 \\
3 \cdot 6\end{array}$ & $\begin{array}{l}28 \cdot 2 \\
4 \cdot 9\end{array}$ & $\begin{array}{l}28 \cdot 7 \\
4 \cdot 2\end{array}$ & $\begin{array}{l}16 \cdot 0 \\
3 \cdot 7\end{array}$ & $\begin{array}{l}15 \cdot 2 \\
3 \cdot 5\end{array}$ & $\begin{array}{l}15 \cdot 6 \\
2 \cdot 6\end{array}$ & $\begin{array}{l}1.90 \\
3.3\end{array}$ & $\begin{array}{l}1 \cdot 76 \\
3 \cdot 4\end{array}$ & $\begin{array}{l}1.82 \\
2.4\end{array}$ \\
\hline$P$ & & 0.0007 & $<0.0001$ & 0.0002 & 0.0006 & 0.0009 & 0.011 & 0.002 & 0.001 & 0.02 \\
\hline
\end{tabular}

* The estimates were all adjusted by a population weighting factor, see p. 192. Series A were not further adjusted; series B were adjusted for age, sex, domicile, selfreported health and energy intake; series $C$ were adjusted for all of these factors and also for regional differences in the use of vitamin $B_{6}$ supplements. 
the vitamin $\mathrm{B}_{6}$ intakes and both of the indices of $\mathrm{B}_{6}$ status exhibited a significant north-south gradient, with the lower intakes and status indices occurring in the north of the country. The significance of this regional variation was not diminished by the inclusion of age, sex, domicile, energy intake and self-reported health (four categories) in the model. Examination of food choices indicated that people living in the south of Britain had greater intakes of several kinds of vitamin $\mathrm{B}_{6}$-providing foods, including potatoes, green vegetables and salads, certain types of fruit, poultry, cheese, and fortified breakfast cereals (results not shown).

\section{Discussion}

Although a number of studies have indicated poor vitamin $\mathrm{B}_{6}$ status and low dietary vitamin $\mathrm{B}_{6}$ intakes in older people (Rose et al. 1976; Kant et al. 1988; Lowik et al. 1989, 1990, 1994; Manore et al. 1989; Euronut SENECA Investigators, 1991; Ribaya-Mercado et al. 1991; Russell \& Suter, 1993; Ferroli \& Trumbo, 1994; Pannemans et al. 1994; Riggs et al. 1996; Bailey et al. 1997), there remains considerable uncertainty about the functional significance and public health importance of this problem. One of the reasons for this uncertainty is the paucity of information about the relative usefulness of the different biochemical indices that have been used to define vitamin $\mathrm{B}_{6}$ status (Leklem, 1990; Driskell, 1994; Kretsch et al. 1995). Plasma pyridoxal phosphate and urinary excretion of pyridoxic acid have both been proposed as status indicators, but there remains a need for clarification of the types of both nutritional and nonnutritional factors which can affect them.

The National Diet and Nutrition Survey: People Aged 65 Years and Over (Finch et al. 1998), together with our linked study of plasma total homocysteine (Bates et al. 1997), has provided an opportunity to re-examine these questions, in the context of a nationally-representative sample of older people living in mainland Britain. Although the task of obtaining a representative sample of older people is not easy, partly because those who are most frail are least likely to agree to participate, several specific precautions were taken to try to ensure that the sample was as representative as possible of the entire (census) population.

The comparisons shown in Tables 1 and 3 show that, whereas plasma pyridoxal phosphate concentrations tend to decline with age and increasing frailty (except for people living in institutions), those of plasma pyridoxic acid clearly increase with age. There were significant interactions between age, sex and type of domicile, particularly with respect to plasma pyridoxal phosphate, indicating that these three factors may affect vitamin $\mathrm{B}_{6}$ status in a complex, interactive manner. An inverse relationship between age and plasma pyridoxal phosphate concentration has previously been reported (Rose et al. 1976; Joosten et al. 1993; Pannemans et al. 1994; Driskell, 1994). Possible reasons for this age trend (Kant et al. 1988; Lowik et al. 1989; Russell \& Suter, 1993) might include: (a) lower vitamin $B_{6}$ intakes in older people; (b) less efficient retention of the vitamin; (c) increased $\mathrm{B}_{6}$ catabolism. Clearly, total vitamin $\mathrm{B}_{6}$ intake and the vita$\min B_{6}$ : energy value tend to decline with age, although the vitamin $\mathrm{B}_{6}$ : protein value does not, and this may, in turn, affect plasma pyridoxal phosphate concentrations. Increased catabolism appears also to be supported by our data. The pyridoxic acid: pyridoxal phosphate value was only 0.22 in young people (Table 4 ) whereas it was 0.5 in people aged 65 years or over, and rose as high as 0.88 in one subgroup (Table 1). This was not entirely a function of renal impairment (see later discussion), because even those older people with low blood concentrations of urea and creatinine had higher pyridoxic acid: pyridoxal phosphate values than young people. The reason for the absence of a decline in plasma pyridoxal phosphate with age in people in institutions is not clear; however, it is likely that people who require institutional care at a relatively early age are more frail than their counterparts living in the community, and that this factor may dominate their status picture.

In contrast to the conclusions of Manore et al. (1989), of the Euronut SENECA Investigators (1991) and of Bailey et al. (1997), the data in Table 3 suggest that plasma pyridoxal phosphate provided a good reflection of dietary intakes of vitamin $\mathrm{B}_{6}$ between individuals. The same was true for pyridoxic acid, which reflected vitamin $\mathrm{B}_{6}$ intakes somewhat more closely at high than at low intakes, and, being a catabolic product, probably reflects the removal of amounts of absorbed vitamin $\mathrm{B}_{6}$ that are greater than normal tissue requirements. The relationships between vitamin $\mathrm{B}_{6}$ intake and its status indices were scarcely affected by the introduction of food energy or protein intakes into the model (Table 3), even though vitamin $\mathrm{B}_{6}$ intake (and to a lesser extent plasma pyridoxal phosphate) was directly correlated with energy and with protein intakes. It is clear from Table 3 that energy (but not protein) intake could independently modulate the relationships between vitamin $\mathrm{B}_{6}$ intake and the status indices, plasma pyridoxal phosphate and plasma pyridoxic acid. The lower the energy intake for a given vitamin $\mathrm{B}_{6}$ intake, the higher the values of these blood status indices. The absence of an independent effect of protein intake on the vitamin $\mathrm{B}_{6}$ status indices is in accord with observations by van der Wielen et al. (1996) who found that in elderly Europeans, the intake of animal protein lost its significance as a predictor of plasma pyridoxal phosphate concentration when vitamin $\mathrm{B}_{6}$ intake was also included in their regression model. Thus, in elderly people, protein intake apparently may act as a weak proxy for vitamin $\mathrm{B}_{6}$ intake if vitamin $\mathrm{B}_{6}$ is not included in the model, but it does not exhibit any inverse relationship with the biochemical indices, which might occur if a high protein intake exerted a metabolic stress on the vitamin $\mathrm{B}_{6}$-dependent pathways of amino acid turnover. Presumably the intake of protein is not great enough for that to occur. The contribution of vitamin $\mathrm{B}_{6}$ from alcoholic drinks and the effect of alcoholic drinks on vitamin $\mathrm{B}_{6}$ status of people participating in the UK survey, is addressed elsewhere (Walmusley et al. 1999). There is a significant increase in vitamin $\mathrm{B}_{6}$ status with the inclusion of moderate amounts of alcoholic drinks in the diet.

A common problem with dietary estimation is that of under-reporting, and an approximate assessment of the extent of this problem, and a prediction of which individuals may be most affected, may be made on the basis of a comparison between calculated BMR (from ages and body weights) and estimates of energy intakes (Department of Health, 1992). However, many older people do lose weight, 
so that a low estimate of energy intake may be perfectly genuine, and not the result of under-reporting. If the lowest third of subjects in the present survey with respect to their estimated energy intake : BMR value, i.e. those with a calculated BMR $<1.06 \times$ estimated energy intake (Goldberg et al. 1991), were omitted from the calculations, the estimated vitamin $\mathrm{B}_{6}$ intake rose by $6 \%$; the vitamin $\mathrm{B}_{6}$ : protein value rose by $2.1 \%$; plasma pyridoxal phosphate rose by $3.0 \%$ and pyridoxic acid fell by $1.1 \%$ (results not shown). Thus the vitamin $\mathrm{B}_{6}$ intake and status indices were not greatly affected by this exclusion procedure, and under-reporting was not considered to be a major issue, with respect to the questions addressed by this study.

With regard to functional significance, many recent studies have focused on plasma homocysteine, as a powerful index and probable cause of increased risk of vascular disease, whose plasma and tissue concentrations respond favourably to improvements in folate, vitamin $\mathrm{B}_{12}$ and vitamin $\mathrm{B}_{6}$ status (Brattstrom et al. 1990; Miller et al. 1992, 1994; Hu et al. 1993; Joosten et al. 1993; Selhub et al. 1993; Ubbink et al. 1993, 1996; Franken et al. 1994; Dalery et al. 1995; Ellis \& McCully, 1995; Naurath et al. 1995; Robinson et al. 1995; Riggs et al. 1996; Verhoef et al. 1996). Vitamin $\mathrm{B}_{6}$ supplements were observed to reduce the raised concentrations of homocysteine seen in patients with cystathionine $\beta$-synthase (EC 4.2.1.22) deficiency, but the role of this vitamin in the commoner forms of mild hyperhomocysteinaemia is less clear. The data in Table 5 show that in a univariate regression model, plasma pyridoxal phosphate level was very strongly correlated with plasma total homocysteine level, but that as other important B-vitamin determinants of homocysteine were added, in a multivariate linear regression model, pyridoxal phosphate lost some of its power of prediction and was therefore less robust as an independent predictor of homocysteine concentrations. The problem of covariance of B-vitamin status indices has complicated the picture; however, the conclusions of the present study are entirely compatible with those of Miller et al. (1992), Selhub et al. (1993), Franken et al. (1994), Ubbink et al. (1996) and Verhoef et al. (1996). The plasma samples used in the present study were nearly all from fasting subjects. The weight of evidence suggests that vitamin $B_{6}$ status is more important as a determinant of plasma homocysteine in non-fasting subjects, and especially following a methionine load (Brattstrom et al. 1990; Miller et al. 1992, 1994; Franken et al. 1994; Ubbink et al. 1996; Mansoor, 1997). The relationship of pyridoxic acid with homocysteine may be confounded by its strong relationship with renal function in older people.

Correlations between the vitamin $\mathrm{B}_{6}$ status indicators and indicators of renal function, namely plasma urea and creatinine, were significant for pyridoxic acid but not for pyridoxal phosphate. Pyridoxic acid is likely to be retained in the blood if renal function is impaired, and vice versa, its excretion is likely to be enhanced if diuretics are used. Correlations which were significant for pyridoxal phosphate but not pyridoxic acid included inverse relationships with plasma $\alpha_{1}$-antichymotrypsin, alkaline phosphatase (EC 3.1.3.1), and leucocyte count, and direct relationships with plasma Zn, albumin, Fe, cholesterol and blood haemoglobin. This constellation of factors may constitute a measure of frailty, and of activation of the acute-phase reaction, since the inverse correlation with $\alpha_{1}$-antichymotrypsin was particularly strong. The strong inverse correlation with alkaline phosphatase may imply an increased rate of degradation of pyridoxal phosphate to free pyridoxal, in people with a high activity of this enzyme (Kant et al. 1988). Factors such as these, and the critical relationship between the timing of dietary estimates and that of phlebotomy for biochemical measurements, may account for some of the discrepancies recorded between previous studies, with respect to the correlations observed between intake estimates and the biochemical picture.

The seasonal variation in plasma pyridoxal phosphate concentrations in the present study, which was not matched by any detectable variation in pyridoxic acid or in vitamin $\mathrm{B}_{6}$ intakes (Table 6), may be linked to winter illness. As noted earlier, plasma pyridoxal phosphate, like plasma retinol, $\mathrm{Fe}, \mathrm{Zn}, \mathrm{Cu}, \mathrm{Se}$ and vitamin $\mathrm{C}$, appears to reflect acutephase status, in addition to specific micronutrient adequacy. Because pyridoxic acid does not appear to share this sensitivity to acute-phase status, it may be able to provide some information about vitamin $\mathrm{B}_{6}$ adequacy which is complementary to that of pyridoxal phosphate. It may, of course, be better to measure pyridoxic acid in urine rather than in plasma, and to express it as the rate of urinary excretion per $24 \mathrm{~h}$, or per unit of creatinine. However, this requires additional fieldwork procedures and additional sample analyses, which increase costs and workload. The strength of the present protocol was that all the biochemical information on vitamin $B_{6}$ status from each subject was obtained in a single chromatographic run, and from a single biological sample.

Table 7 shows that pyridoxal phosphate, pyridoxic acid, and vitamin $\mathrm{B}_{6}$ intakes all exhibited a significant northsouth geographical gradient, consistent with evidence (Bates et al. 1997; Finch et al. 1998) that B-vitamin-rich foods are less frequently used by people living in the north than in the south of Britain.

With the previously-proposed lower cut-off limit for normal vitamin $\mathrm{B}_{6}$ status of $30 \mathrm{nmol}$ pyridoxal phosphate/l plasma (Leklem, 1990; Driskell, 1994), 561/1175 $=47.7 \%$ of the survey participants were found to have subnormal status (see Bailey et al. 1997). For those living in institutions, this proportion was even higher at $190 / 255=75.5 \%$. With the more conservative cut-off value of $20 \mathrm{nmol} / \mathrm{l}$, used by the Euronut SENECA Investigators (1991), the proportion of biochemically deficient values was $24.5 \%$ overall and $46 \%$ of those in institutions. Of the $24.5 \%$ with plasma pyridoxal phosphate concentrations below $20 \mathrm{nmol} / 1,72 \%$ also had pyridoxic acid concentrations below the median value of $15 \mathrm{nmol} / \mathrm{l}$. This estimate of $24.5 \%$ biochemical deficiency is very close to the estimate of $23.3 \%$ for older people living in other European countries (Euronut SENECA Investigators, 1991). Low vitamin $\mathrm{B}_{6}$ status in elderly Americans living in institutions has also been reported previously (Russell \& Suter, 1993).

Ribaya-Mercado et al. (1991) found, in a metabolic wardbased study with controlled intakes, that healthy elderly people required a daily intake of about $1.90-1.96 \mathrm{mg}$ vitamin $\mathrm{B}_{6}$ to achieve adequate status. If the calculations in the previous paragraph are applied to those National Diet 
and Nutrition Survey participants ( $n$ 525) whose estimated vitamin $\mathrm{B}_{6}$ intakes were $1.96 \mathrm{mg} / \mathrm{d}$ or greater, $27 \%$ had plasma pyridoxal phosphate concentrations below $30 \mathrm{nmol} / \mathrm{l}$ and $11 \%$ had concentrations below $20 \mathrm{nmol} / \mathrm{l}$. Of the eighty people in institutions with intakes of $1.96 \mathrm{mg}$ vitamin $\mathrm{B}_{6} / \mathrm{d}$ or greater, $65 \%$ had plasma pyridoxal phosphate concentrations below $30 \mathrm{nmol} / \mathrm{l}$ and $32 \%$ had concentrations below $20 \mathrm{nmol} / \mathrm{l}$. This might suggest that an intake that has been deemed to be adequate does not always result in adequate status. However, the individual vitamin $\mathrm{B}_{6}$ intake estimates in the survey may not have been truly representative of long-term intakes, and comparisons with metabolic ward studies are, thus, not always easy to interpret.

In contrast to the biochemical picture, which seems to indicate a high prevalence of vitamin $\mathrm{B}_{6}$ deficiency in older British people, the estimated vitamin $\mathrm{B}_{6}$ intakes in this study population did not appear to be low in relation to the dietary reference values (Department of Health, 1991), which are calculated as a ratio to protein intakes. The mean intake of vitamin $\mathrm{B}_{6}$ overall was $152 \%$ of the reference nutrient intake in men and $134 \%$ in women. Only $2 \%$ of men and $3 \%$ of woman had estimated vitamin $\mathrm{B}_{6}$ intakes below the lower reference nutrient intake (Finch et al. 1998). A very similar picture was observed by Bailey et al. (1997). We now need to ask: are the dietary reference values set too low for older people?; is the ratio to protein entirely appropriate for people with low protein intakes?; is the biochemical index cut-off limit set too high?, or are there complex metabolic reasons why the biochemical index may not accurately reflect vitamin $\mathrm{B}_{6}$ status in older people? Similar questions also need to be asked for many other micronutrients, in older people.

Since vitamin $\mathrm{B}_{6}$ status probably affects immune function (Talbott et al. 1987) and cognitive performance (Riggs et al. 1996) in older people, such questions about vitamin $B_{6}$ adequacy seem highly relevant for the definition of public health nutrition policy and priorities.

\section{Acknowledgements}

The National Diet and Nutrition Survey of People Aged 65 Years and Over was funded jointly by the Ministry of Agriculture, Fisheries and Food and the Department of Health, and conducted by Social and Community Planning Research, in conjunction with the Medical Research Council's Dunn Nutrition Unit. The authors acknowledge financial support for this further analysis of the survey data from The Royal Society and the Department of Health, and they thank Dr T. J. Cole for statistical advice, Dr P. C. Clarke and Miss G. E. Smithers for helpful discussions, and $\mathrm{Mr} \mathrm{A}$. Macdonald and $\mathrm{Mr} \mathrm{N}$. Matthews for their assistance with the assays.

\section{References}

Bailey AL, Maisey S, Southon S, Wright AJA, Finglas PM \& Fulcher RA (1997) Relationships between micronutrient intake and biochemical indicators of nutrient adequacy in a 'freeliving' elderly UK population. British Journal of Nutrition 77, 225-242.

Bates CJ (1997) Vitamin analysis. Annals of Clinical Biochemstry 34, 1-27.
Bates CJ, Mansoor MA, van der Pols J, Prentice A, Cole TJ \& Finch S (1997) Plasma total homocysteine in a representative sample of 972 British men and women aged 65 and over. European Journal of Clinical Nutrition 51, 1-7.

Bates CJ, Pentieva KD, Matthews N \& MacDonald A (1998) A simple, sensitive and reproducible assay for pyridoxal $5^{\prime}$-phosphate and 4-pyridoxic acid in human plasma. Clinica Chimica Acta (In the Press).

Boushey CJ, Beresford SA, Omenn GS \& Motulsky AG (1995) A quantitative assessment of plasma homocysteine as a risk factor for vascular disease: probable benefits of increasing folic acid intakes. Journal of the American Medical Association 274, 1049-1057.

Brattstrom L, Israelsson B, Norrving B, Bergqvist D, Thorne J, Hultberg B \& Hamfelt A (1990) Impaired homocysteine metabolism in early-onset cerebral and peripheral occlusive arterial disease. Effects of pyridoxine and folic acid treatment. Atherosclerosis 81, 51-60.

Chen LH \& Fan-Chiang WL (1981) Biochemical evaluation of riboflavin and vitamin $\mathrm{B}_{6}$ status of institutionalised and noninstitutionalised elderly in Central Kentucky. International Journal of Vitamin and Nutrition Research 51, 232-238.

Dalery K, Lussier-Cacan S, Selhub J, Davignon J, Latour Y \& Genest J (1995) Homocysteine and coronary artery disease in French Canadian subjects: relation with vitamins $\mathrm{B}_{12}, \mathrm{~B}_{6}$, pyridoxal phosphate and folate. American Journal of Cardiology 75, 1107-1111.

Department of Health (1991) Dietary Reference Values for Food Energy and Nutrients for the United Kingdom. Report on Health and Social Subjects no. 41. London: H. M. Stationery Office.

Department of Health (1992) The Nutrition of Elderly People. Report on Health and Social Subjects no. 43. London: H. M. Stationery Office.

Driskell JA (1994) Vitamin B-6 requirements of humans. Nutrition Research 14, 293-324.

Ellis JM \& McCully KS (1995) Prevention of myocardial infarction by vitamin $\mathrm{B}_{6}$. Research Communications in Molecular Pathology and Pharmacology 89, 208-220.

Euronut SENECA Investigators (1991) Nutritional status: blood vitamins $\mathrm{A}, \mathrm{E}, \mathrm{B}_{6}, \mathrm{~B}_{12}$, folic acid and carotene. European Journal of Clinical Nutrition 45, Suppl. 3, 63-82.

Ferroli CE \& Trumbo PR (1994) Bioavailability of vitamin B-6 in young and older men. American Journal of Clinical Nutrition 60, 68-71.

Finch S, Doyle W, Lowe C, Bates CJ, Prentice A, Smithers G \& Clarke PC (1998) National Diet and Nutrition Survey: People Aged 65 Years and Over. Vol. 1. Report of the Diet and Nutrition Survey. London: The Stationery Office (In the Press).

Franken DG, Boers GHJ, Blom HJ \& Trijbels JMF (1994) Effect of various regimens of vitamin $B_{6}$ and folic acid on mild hyperhomocysteinaemia in vascular patients. Journal of Inherited and Metabolic Diseases 17, 159-162.

Goldberg GR, Black AE, Jebb SA, Cole TJ, Murgatroyd PR, Coward WA \& Prentice AM (1991) Critical evaluation of energy intake data using fundamental principles of energy physiology: 1. Derivation of cut-off limits to identify underrecording. European Journal of Clinical Nutrition 45, 569-581.

Graham IM, Daly LE, Refsum HE, Robinson K, Brattstrom LE, Ueland PM, Palma-Reis RJ, Boers GHJ, Sheahan RG, Israelsson B, Uiterwaal CS, Meleady R, McMaster D, Verhoef P, Witterman J, Rubba P, Bellet H, Wautrecht JC, de Valk HW, Luis ACS, Parrot-Roulaud FM, Tan KS, Higgins I, Garcon D, Medrano MJ, Candito M, Evans AE \& Andria G (1997) Plasma homocysteine as a risk factor for vascular disease. The European concerted action project. Journal of the American Medical Association 277, 1775-1781.

Hu FL, Gu Z, Kozich V, Kraus JP, Ramesh V \& Shih VE (1993) 
Molecular basis of cystathionine $\beta$-synthase deficiency in pyridoxine responsive and non-responsive homocystinuria. Human Molecular Genetics 2, 1857-1860.

Joosten E, van den Berg A, Riezler R, Naurath HJ, Lindenbaum J, Stabler SP \& Allen RH (1993) Metabolic evidence that deficiencies of vitamin $\mathrm{B}_{12}$ (cobalamin), folate, and vitamin $\mathrm{B}_{6}$ occur commonly in elderly people. American Journal of Clinical Nutrition 58, 468-476.

Kant AK, Moser-Veillon PB \& Reynolds RD (1988) Effect of age on changes in plasma, erythrocyte, and urinary B-6 vitamers after an oral vitamin B-6 load. American Journal of Clinical Nutrition 48, 1284-1290.

Kretsch MJ, Sauberlich HE, Skala JH \& Johnson HL (1995) Vitamin $\mathrm{B}_{6}$ requirements and status assessment: young women fed a depletion diet followed by a plant- or animal-protein diet with graded amounts of vitamin $\mathrm{B}_{6}$. American Journal of Clinical Nutrition 61, 1091-1101.

Leklem JE (1990) Vitamin B-6: a status report. Journal of Nutrition 120, 1503-1507.

Lowik MRH, Schrijver J, van den Berg H, Hulshof KFAM, Wedel M \& Ockhuizen T (1990) Effect of dietary fiber on the vitamin $\mathrm{B}_{6}$ status among vegetarian and non-vegetarian elderly (Dutch Nutrition Surveillance System). Journal of the American College of Nutrition 9, 241-249.

Lowik MRH, van den Berg H, Kistemaker C, Brants HAM \& Brussaard JH (1994) Interrelationships between riboflavin and vitamin $\mathrm{B}_{6}$ among elderly people (Dutch Nutrition Surveillance System). International Journal of Vitamin and Nutrition Research 64, 198-203.

Lowik MRH, van den Berg H, Schrijver J, Odink J, Wedel M \& van Houten P (1992) Marginal nutritional status among institutionalised elderly women as compared to those living more independently (Dutch Nutrition Surveillance System). Journal of the American College of Nutrition 11, 673-681.

Lowik MRH, van den Berg H, Westenbrink S, Wedel M, Schrijver J \& Ockhuizen T (1989) Dose-response relationships regarding vitamin $\mathrm{B}_{6}$ in elderly people: a nationwide nutritional survey (Dutch Nutritional Surveillance System). American Journal of Clinical Nutrition 50, 391-399.

Manore MM, Vaughan LA, Carroll SS \& Leklem JE (1989) Plasma pyridoxal $5^{\prime}$ phosphate concentration and dietary vitamin $\mathrm{B}_{6}$ intake in free-living, low-income elderly people. American Journal of Clinical Nutrition 50, 339-345.

Mansoor MA (1997) Hyperhomocysteinaemia and premature coronary artery disease in the Chinese. Heart 77, 390.

Mansoor MA, Svardal AM \& Ueland PM (1992) Determination of the in vivo redox status of cysteine, cysteinylglycine, homocysteine and glutathione in human plasma. Analytical Biochemistry 200, 218-229.

Miller JW, Nadeau MR, Smith D \& Selhub J (1994) Vitamin B-6 deficiency vs folate deficiency: comparison of responses to methionine loading in rats. American Journal of Clinical Nutrition 59, 1033-1039.

Miller JW, Ribayo-Mercado JD, Russell RM, Shepard DC, Morrow FD, Cochary EF, Sadowski JA, Gershoff SN \& Selhub J (1992) Effect of vitamin B-6 deficiency on fasting plasma homocysteine concentrations. American Journal of Clinical Nutrition 55, 1154-1160.

Naurath HJ, Joosten E, Riezler R, Stabler SP, Allen RH \& Lindenbaum J (1995) Effects of vitamin $B_{12}$, folate, and vitamin
$\mathrm{B}_{6}$ supplements in elderly people with normal serum vitamin concentrations. Lancet 346, 85-89.

Pannemans DLE, van den Berg H \& Westerterp KR (1994) The influence of protein intake on vitamin B-6 metabolism differs in young and elderly humans. Journal of Nutrition 124, 12071214.

Ribaya-Mercado JD, Russell RM, Sahyoun N, Morrow FD \& Gershoff SN (1991) Vitamin $B_{6}$ requirements of elderly men and women. Journal of Nutrition 121, 1062-1074.

Riggs KM, Spiro A III, Tucker K \& Rush D (1996) Relations of vitamin $\mathrm{B}-12$, vitamin $\mathrm{B}-6$, folate and homocysteine to cognitive performance in the Normative Aging Study. American Journal of Clinical Nutrition 63, 306-314.

Robinson K, Mayer EL, Miller DP, Green R, van Lente F, Gupta A, Kottke-Marchant K, Savon SR, Selhub J, Nissen SE, Jutner M, Topol EJ \& Jacobsen DW (1995) Hyperhomocysteinaemia and low pyridoxal phosphate. Common and independent reversible risk factors for coronary artery disease. Circulation 92, 28252830.

Rose CS, Gyorgy P, Butler M, Andres R, Norris AH, Shock NW, Tobin J, Brin M \& Spiegel H (1976) Age differences in vitamin $\mathrm{B}_{6}$ status of 617 men. American Journal of Clinical Nutrition 29, $847-853$.

Russell RM \& Suter PM (1993) Vitamin requirements of elderly people: an update. American Journal of Clinical Nutrition 58, 4-14.

Selhub J, Jacques PF, Wilson PWF, Rush D \& Rosenberg I (1993) Vitamin status and intake as primary determinants of homocysteinaemia in an elderly population. Journal of the American Medical Association 270, 2693-2698.

Smolin LA \& Benevenga NJ (1982) Accumulation of homocyst(e)ine in vitamin B-6 deficiency: a model for the study of cystathionine $\beta$-synthase deficiency. Journal of Nutrition 112, 1264-1272.

Talbott MC, Miller LT \& Kerkvliet NI (1987) Pyridoxine supplementation: effect on lymphocyte responses in elderly persons. American Journal of Clinical Nutrition 46, 659-664.

Ubbink JB, van der Merwe A, Delport R, Allen RH, Stabler SP, Riezler R \& Vermaak WJH (1996) The effect of a subnormal vitamin B-6 status on homocysteine metabolism. Journal of Clinical Investigation 98, 177-184.

Ubbink JB, Vermaak WJH, van der Merwe A \& Becker PJ (1993) Vitamin B-12, vitamin B-6 and folate nutritional status in men with hyperhomocysteinaemia. American Journal of Clinical Nutrition 57, 47-53.

Van der Wielen RPJ, Lowick MRH, Haller J, van den Berg H, Ferry M \& van Staveren WA (1996) Vitamin B-6 malnutrition among elderly Europeans: the SENECA study. Journal of Gerontology 51A, B417-B424.

Verhoef P, Stampfer MJ, Buring JE, Gaziano JM, Allen RH, Stabler SP, Reynolds RD, Kok FJ, Hennekens CH \& Willett WC (1996) Homocysteine metabolism and risk of myocardial infarction: relation with vitamins $\mathrm{B}_{6}, \mathrm{~B}_{12}$ and folate. American Journal of Epidemiology 143, 845-859.

Walmusley CM, Bates CJ, Prentice A \& Cole TJ (1999) Relationship between alcohol and nutrient intakes and blood status indices of older people living in the UK: further analysis of data from the National Diet and Nutrition Survey of people aged 65 years and over, 1994/5. Public Health Nutrition 1, 157167. 


\section{Proceedings of the Nutrition Society}

Editor: K M Younger
Dublin, Ireland

(1D) CABI Publishing
Throughout the year, The Nutrition Society holds important meetings and symposia, often in collaboration with other learned societies, where international experts are invited to speak on topics of particular interest in nutritional science.

The 1999 volume will feature papers and abstracts presented at Nutrition Society Symposia including:

- Meat or wheat for the next millennium?

- Effect of diet on lipoproteins involved in cardiovascular disease

- Bioavailability of micronutrients

- Optimal versus adequate nutrition

- Functionality of nutrients: behaviour, safety, gene expression and food technology

All this key information can be at your fingertips during 1999 by subscribing to the Proceedings of the Nutrition Society.

Published quarterly ISSN: $00296651 \quad$ 1999, Volume 58 $£ 240.00$ (US $\$ 425.00$ Americas only)

Order your 1999 subscription now!

(10) $C A B \mid$ Publishing

CAB International

Wallingford, Oxon, OX10 8DE, UK

Tel: $+44(0) 1491832111$

Fax: +44 (0)1491 829292

Email:publishing@cabi.org

\section{(10) CABI Publishing}

CAB International

10 East 40th Street, Suite 3203,

New York, NY 10016, USA

Tel: +1 (212) 4817018

Toll-free: 18005284841

Fax: +1 (212) 6867993

Email:cabi-nao@cabi.org 